\begin{tabular}{|c|c|c|}
\hline WA: & 1. EOT & 615719 \\
\hline
\end{tabular}

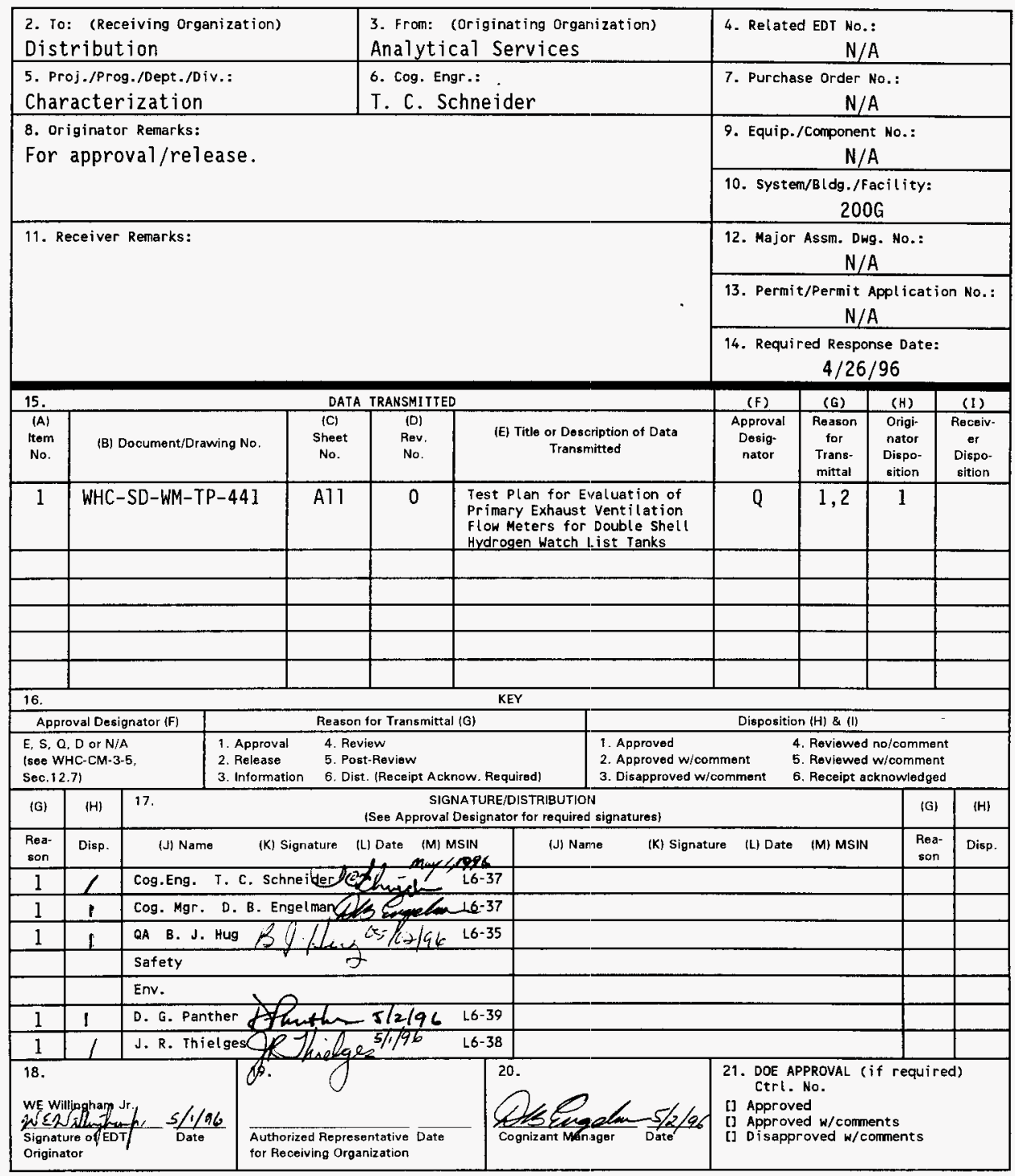




\title{
Test Plan for Evaluation of Primary Exhaust Ventilation Flow Meters for Double Shell Hydrogen Watch List Tanks
}

\author{
W. E. Willingham Jr. \\ ICF Kaiser Hanford Company, Richland, WA 99352 \\ U.S. Department of Energy Contract DE-AC06-87RL10930

$\begin{array}{lll}\text { EDT } / E C N: & 615719 & \text { UC: } 2070 \\ \text { Org Code: } & 5 A 620 & \text { Charge Code: N2169 } \\ \text { B\&R Code: } & \text { EW3120072 } & \text { Total Pages: } 26\end{array}$

Key Words: test plan, flow, ventilation, double shell tanks, watch list

Abstract: This document is a plan for testing four different flow meters for use in the primary exhaust ventilation ducts of Double She 11 Tanks on the hydrogen watch list that do not already have this capability. This currently includes tanks 241-AW-101, 241-AN-103, 241AN-104, 241-AN-105 and 241-SY-103. The anticipated airflow velocity in these tanks range from $0.25 \mathrm{~m} / \mathrm{s}(50 \mathrm{ft} / \mathrm{min})$ to $1.78 \mathrm{~m} / \mathrm{s}(350 \mathrm{ft} / \mathrm{min})$. Past experiences at Hanford are forcing the evaluation and selection of instruments to be used at the low flow and relatively high humidity conditions found in these tanks. Based on the results of this test, a flow meter shall be chosen for installation in the primary exhaust ventilation ducts of the above mentioned waste tanks.

TRADEMARK OISCLAIMER. Reference herein to any specific commercial product, process, or service by trade naine, trademark, manufacturer, or otherwise, does not necessarily constitute or imply its endorserient, recommendation, or favoring by the United States Goverment or any agency thereof or its contractors or subcontractors.

Printed in the United States of America. To obtain copies of this document, contact: WHC/BCS Document Control Services, P.O. Box 1970, Mailstop H6-08, Richtand wA 99352, Phone (509) 372-2420; Fax (509) 376-4989.
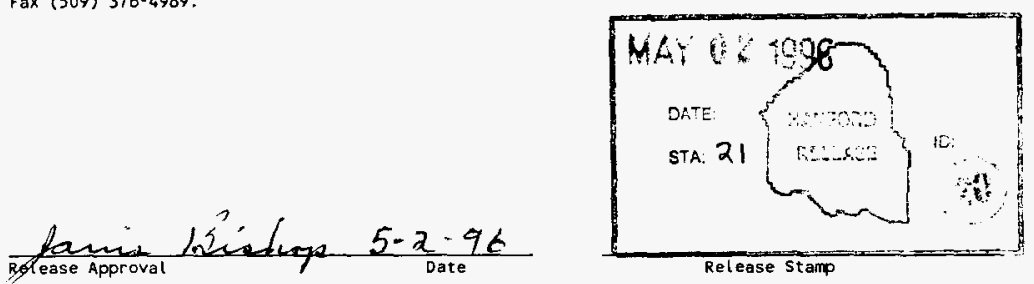

Approved for Public Release 
TEST PLAN FOR EVALUATION OF PRIMARY EXHAUST VENTILATION FLOW METERS FOR DOUBLE SHELL HYDROGEN WATCH LIST TANKS

Contents

1.0 INTRODUCTION . . . . . . . . . . . . . . . . . . . . . . 1

2.0 Objective . . . . . . . . . . . . . . . . . . . . . . . . 1

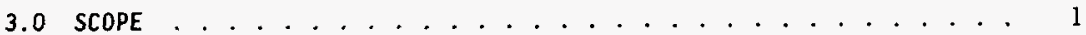

4.0 DESCRIPTION OF TEST . . . . . . . . . . . . . . . . . . . . 2

5.0 EXPECTED RESULTS . . . . . . . . . . . . . . . . . . . . . . 4

6.0 TEST PROCEDURE . . . . . . . . . . . . . . . . . . . . . . . 4

7.0 SAFETY . . . . . . . . . . . . . . . . . . . . 12

8.0 QUALITY ASSURANCE . . . . . . . . . . . . . . . . . . . . 13

9.0 ORGANIZATION AND FUNCTION RESPONSIBILITIES . . . . . . . . . . . . . 13

10.0 SCHEDULE . . . . . . . . . . . . . . . . . . . . . . . 13

11.0 REPORTS . . . . . . . . . . . . . . . . . . . . . . 13

12.0 REFERENCES . . . . . . . . . . . . . . . . . . . . . 14

FIGURE 1 - FLOW METER TEST SETUP . . . . . . . . . . . . . . . . . . . . 15

FIGURE 2 - INSERTION-TYPE FLOW METER MOUNTING . . . . . . . . . . . . . . 16

FIGURE 3 - ULTRASONIC FLOW METER MOUNTING . . . . . . . . . . . . . . . . 17

TEST EQUIPMENT DATA SHEET . . . . . . . . . . . . . . . . . . . . . . . . 18

FLOW METER TEST DATA SHEET - AMBIENT, PAgE A . . . . . . . . . . . . . . 19

FLOW METER TEST DATA SHEET - AMBIENT, PAGE B . . . . . . . . . . . . . . 20

FLOW METER TEST DATA SHEET - HIGH HUMIDITY . . . . . . . . . . . . . . . 2 I

FLOW METER STABILITY TEST DATA SHEET . . . . . . . . . . . . . . . . . . 22

STEP RESPONSE TEST DATA SHEET . . . . . . . . . . . . . . . . . . . 23

FLOW AND VELOCITY REFERENCE TABLE . . . . . . . . . . . . . . . . . . . . 24 
WHC-SD-WM-TP-441 REV 0

\section{TEST PLAN FOR EVALUATION OF PRIMARY EXHAUST VENTILATION FLOW METERS FOR DOUBLE SHELL HYOROGEN WATCH LIST TANKS}

\subsection{INTRODUCTION}

This document is a plan for testing four different flow meters for use in the primary exhaust ventilation ducts of Double Shell Tanks on the hydrogen watch list that do not already have this capability. This currently includes tanks 241-AW-101, 241-AN-103, 241-AN-104, 241-AN-105 and 241-SY-103. The anticipated airflow velocity in these tanks range from $0.25 \mathrm{~m} / \mathrm{s}(50 \mathrm{ft} / \mathrm{min})$ to $1.78 \mathrm{~m} / \mathrm{s}(350 \mathrm{ft} / \mathrm{min})$. Past experiences at Hanford are forcing the evaluation and selection of instruments to be used at the low flow and relatively high humidity conditions found in these tanks.

\subsection{OBJECTIVE}

This plan provides a controlled method of evaluating the low flow performance of four previously selected flow meters. Based on the results of this test, a flow meter shall be chosen for installation in the primary exhaust ventilation ducts of the above mentioned waste tanks.

The objective of this testing is to measure the accuracy, step response and response to high humidity of the four flow meters over the velocity range of $0.066 \mathrm{~m} / \mathrm{s}(13 \mathrm{ft} / \mathrm{min})$ to $2.25 \mathrm{~m} / \mathrm{s}(442 \mathrm{ft} / \mathrm{min})$ [ flow range of $4.7 \mathrm{E}-3 \mathrm{~m}^{3} / \mathrm{s}(10$ $\mathrm{cfm})$ to $0.16 \mathrm{~m}^{3} / \mathrm{s}(340 \mathrm{cfm})$ for our 12" duct]. A full scale mock-up of a typical exhaust duct in the valve pits will be used for testing because the duct configuration is less than optimum for flow instrumentation. Flow meters generally work best with laminar flow through the duct being used. Typically, the flow meter vendors desire five diameters of straight duct downstream of the flow meter and ten to twenty diameters of straight duct upstream of the flow meter to provide accurate readings. In our typical valve pit arrangement we have only ten diameters of unperturbed duct in which to position the flow element.

Testing will be considered complete after all four flow meters have been tested per the test procedure contained herein.

\subsection{SCOPE}

A full-scale mockup of the ductwork in a typical tank farm ventilation pit will be set up in the $306 \mathrm{E}$ Building in the 300 Area. To determine flow meter accuracy a controlled and measured volume of air will be sent through the ductwork $\left(4.7 \mathrm{E}-3\right.$ to $\left.0.16 \mathrm{~m}^{3} / \mathrm{s}\right)$ and will be measured by the four flow meters to be tested. A calibrated laminar flow element in an ideal configuration will be used as the basis of comparison.

The step response of the flow meters will be tested also. The requirement is for a $10 \%$ to $90 \%$ of step response time of less than ten seconds for a $50 \%$ increase or decrease from the nominal flow rate.

The response to humidity will be tested by introducing moisture into the airstream with a spray nozzle to maintain a relative humidity range 
of $50 \%-90 \%$. Each flow meter will measure a constant flow over a forty-eight hour period to determine the effect of the humidity.

A stability test will be performed by holding the flow at a steady rate for 24 hours at ambient temperature and humidity.

The need for additional tests may develop as the testing progresses. For example, the effect of probe insertion depth may be examined as well as the effect of the butterfly valve position. In any case, no testing will exceed the safety scope herein defined. These additional test will be documented in the test $\log$ and reported in the test report.

\subsection{DESCRIPTION OF TEST}

\subsection{Test Item}

The four flow meters to be tested are listed as follows:

- Air Monitor Corporation MASS-tron II and Volu-probe/1. The MASS-tron II is an ultra-low range differential pressure transmitter that is used in conjunction with the Volu-probe/l airflow traverse probe. The traverse probe measures total pressure and static pressure across the diameter of the duct. The difference of these two pressures is the velocity pressure, which is proportional to air velocity. An airstream temperature signal (4-20 mA) is an additional input signal used by the MASS-tron II to calculate and output the actual volumetric flow rate. The specified output of the MASS-tron II is a 4-20 mA signal (0-397 ACFM). The standard volumetric flow rate can be calculated if the gas pressure and gas mass density at actual conditions are known.

o Intek, Inc. Rheotherm Model IIID-IXD-NPT/2I(ADJ)-4/20-ISB. (Rheotherm and Intek are registered trademarks of Intek, Inc.) The Rheotherm Mode] IIID is a thermal mass flow meter that measures ambient temperature inside the duct and then heats an adjacent RTD to a set difference above ambient. The air molecules flowing past the heated element take away heat proportional to the velocity of the airflow. The specified output of the Rheotherm is a 4-20 mA signal proportional to the standard volumetric flow rate (SCFM), but is linear only over the 6-20 mA range (45-350 SCFM).

- Panametrics Model GP68 General Purpose Flowmeter. The Model GP68 is a transit time ultrasonic flow meter. Two transducers are mounted at a forty-five degree angle across the diameter of the duct. Ultrasonic pulses are sent both upstream and downstream and the difference in puise transit time is proportional to the airflow velocity. The specified output of the GP68 is a 4-20 mA signal proportional to the actual volumetric flow rate (ACFM) and is programmable in the range of 5 to 7000 ACFM for a 12" diameter duct. The standard volumetric flow rate can be calculated if the gas pressure and gas mass density at actual conditions are known.

o Sierra Instruments, Inc. Model 640-FM-L13-E2-PV1-V4-NR. The Model 640 is another thermal mass flow meter. It is similar in operation to the Rheotherm Model IIID. The specified output of the Model 640 is 
a 4-20 $\mathrm{mA}$ signal proportional to the standard volumetric flow rate (SCFM), linear over the entire 4-20 mA range (0-300 SCFM).

\subsection{Test Environment}

Normal testing will take place in the high bay of the $306 \mathrm{E}$ Laboratory in the 300 Area under ambient temperature and humidity conditions. The high humidity portion of the test will require the addition of moisture into the airstream to increase the relative humidity to 50 to 90 percent.

\subsection{Equipment and Facilities}

A full-scale mockup of the ductwork in a typical ventilation pit will be required for this testing. See Figure 1 for design details.

The building utilities required will be 240 VAC power for the air supply system, 120 VAC power for the instrumentation, compressed air, and a water source.

The instruments required for testing are listed below. An equivalent instrument approved by the Test Director may be used if the specified instrument is not available.

- Laminar Flow Element, Meriam Instrument Model 50MC2-4, nominal 400 scfm air flow at 8" WC and 70 degrees $F$ and $29.92^{\prime \prime} \mathrm{Hg}$ abs.

- Ashcroft ATE-100 Handheld Pressure Calibrator, Port 1: 0-25 in. $\mathrm{H}_{2} \mathrm{O}$ input range, Port 2: 0-30 psia input range. Output via RS-232 port.

- Absolute Pressure Transmitter, Rosemount Model 3051C, 0-30 psia input range, 4-20 mA output.

- RTD, Platinum, 100 Ohm, DIN 385, Gordon Model RFHLOTK100CA200

- Temperature Indicator/Transmitter, Newport Electronics Model INFU-0010-DC1. Configured for a DIN 385 4-wire 100 ohm RTD.

- Computer, IBM PC/XT/AT or compatible, with data acquisition software installed

- Data acquisition hardware to match software

- Power Supply, 120V AC input, 24V OC output, to support pressure instruments, humidity probe and MASStron II flow meter.

- Humidity probe, 4-20 mA output proportional to 0-100\% relative humidity

\subsection{Data}

The test data will be collected by the computer as well as written down on the test data sheet. The test data sheets will record the name of the device under test (DUT), the air flow temperature and static pressure, the reference flow and the measured flow. 
The computer data will be stored on disks untill the end of the test whereupon the data can be retrieved and analyzed to determine the results of the tests.

\subsection{Criteria/Constraints}

Testing will be halted if the ambient temperature falls outside the range of -20 to 120 degrees $F$ or if other abnormal environmental conditions develop. Prior to the start of testing, all test instrurnents must be in current calibration and functioning properly.

\subsection{EXPECTED RESULTS}

The tests will be successful if three criteria are met:

- The flow meters track the reference flow meter within $\pm 0.08 \mathrm{~m} / \mathrm{s}$ (15 $\mathrm{ft} / \mathrm{min}$ ) over the range of 0.15 to $2.03 \mathrm{~m} / \mathrm{s}(30$ to $400 \mathrm{ft} / \mathrm{min})$.

- High humidity does not affect the measured flow velocity (nominal 0.798 $\mathrm{m} / \mathrm{s}(156 \mathrm{ft} / \mathrm{min}))$ by more than $\pm 0.08 \mathrm{~m} / \mathrm{s}(15 \mathrm{ft} / \mathrm{min})$ over a forty-eight hour period.

- The $10 \%$ to $90 \%$ step response times of the flowmeters to a $50 \%$ increase or decrease from the nominal flow rate is less than ten seconds.

\subsection{TEST PROCEDURE}

The test may be interrupted at any point for maintenance or failures. If adjustments to the test apparatus are required they must be recorded on the test data sheet and test $10 \mathrm{~g}$. Restart of the testing should resume as determined by the test performer. The testing will restart at such a point to completely retest the interrupted evolution.

The following procedure steps assume that the test performer is familiar with the operation of the flow meters and the data acquisition system, and that the vendor manuals are available for reference.

Specific procedure steps will not be given. The following outline for testing will result in completion of the Test Data Sheets for each flow meter to be tested.

\subsection{Equipment Setup and Checkout}

Set up the valve pit mockup as detailed in Figure 1. Verify that the air flow through the system is adjustable from 10 to 340 SCFM.

\subsection{Test Instrument Documentation}

Record the instrument model number, serial number, and calibration data on the Test Equipment Data Sheet. 
WHC-SD-WM-TP-441 REV 0

\subsection{Ambient Condition, Step Response and Stability Testing}

\subsubsection{Sierra Flow Meter Testing}

- Install the flow meter where indicated in Figure 1 using the saddle clamp provided as shown in Figure 2.

- Connect power to the flow meter and connect its 4-20 mA output to the data acquisition system.

- Program the flow meter per the manufacturer's instructions to measure flow in the $0-400$ SCFM range.

- Fill out the top of the Flow Meter Test Data Sheets (A and B).

- Start the blower and set the air flow as shown in the Nominal Air Flow Column on the Test Data Sheet. Allow the airflow to stabilize. Record the airstream temperature, the reference differential pressure, the reference static air pressure, the output of the flow meter being tested and the test flow meter static pressure. Repeat these steps until the Test Data Sheet is filled out.

- Fill out the top of a Flow Meter Step Response Test Data Sheet.

- Set the nominal airflow through the system to 50 SCFM. Use the two gate valves near the blower to adjust the airflow through the bypass port such that when the bypass is capped off the flow through the system increases to 75 SCFM ( $50 \%$ increase).

- After the airflow has stabilized at 50 SCFM, start the data acquisition system to record data every second. Wait ten seconds and then cap off the bypass port. Wait thirty seconds. Remove the cap from the bypass port. Wait thirty seconds. Stop the data acquisition system.

- Install the cap on the bypass port and set the nominal airflow through the system at 50 SCFM. Remove the cap and adjust the bypass valve to adjust the airflow through the system measures 25 SCFM (50\% decrease).

- Reinstall the bypass cap and allow the airflow to stabilize at 50 SCFM. Start the data acquisition system to record data every second. Wait ten seconds and then remove the cap from the bypass port. Wait thirty seconds. Reinstall the cap on the bypass port. Wait thirty seconds. Stop the data acquisition system.

- Set the nominal airflow through the system to 120 SCFM. Use the two gate valves near the blower to adjust the airflow through the bypass port such that when the bypass is capped off the flow through the system increases to 180 SCFM (50\% increase).

- After the airflow has stabilized at 120 SCFM, start the data acquisition system to record data every second. Wait ten seconds and then cap off the bypass port. Wait thirty seconds. Remove the cap from the bypass port. Wait thirty seconds. Stop the data acquisition system. 
- Instali the cap on the bypass port and set the nominal airflow through the system at 120 SCFM. Remove the cap and adjust the bypass valve to adjust the airflow through the system measures 60 SCFM ( $50 \%$ decrease).

- Reinstall the bypass cap and allow the airflow to stabilize at 120 SCFM. Start the data acquisition sy'stem to record data every second. Wait ten seconds and then remove the bypass port. Wait thirty seconds. Reinstall the cap on the bypass port. Wait thirty seconds. Stop the data acquisition system.

- Fill out the top of a Flow Meter Stability Test Data Sheet.

- Start the air supply system and set the air flow to $160 \mathrm{ft} / \mathrm{min}$. Allow the airflow to stabilize. Start the data acquisition system to automatically log data for the next 24 hours. Record the airstream temperature, the reference differential pressure, the reference static air pressure, the output of the flow meter being tested, the test flow meter static pressure and the system relative humidity.

- After the 24 hours has elapsed, stop the air supply system, evaluate the test data, and determine if any additional testing is required. If not, proceed with the next flow meter.

\subsubsection{Intek Flow Meter Testing}

- Install the flow meter where indicated in Figure 1 using the saddle clamp provided as shown in Figure 2.

- Connect power to the flow meter and connect its 4-20 mA output to the data acquisition system.

- Program the flow meter per the manufacturer's instructions to measure flow in the $0-400$ SCFM range.

- Fill out the top of the Flow Meter Test Data Sheets (A and B).

- Start the blower and set the air flow as shown in the Nominal Air Flow Column on the Test Data Sheet. Allow the airflow to stabilize. Record the airstream temperature, the reference differential pressure, the reference static air pressure, the output of the flow meter being tested and the test flow meter static pressure. Repeat these steps until the Test Data Sheet is filled out.

- Fill out the top of a Flow Meter Step Response Test Data Sheet.

- Set the nominal airflow through the system to 50 SCFM. Use the two gate valves near the blower to adjust the airflow through the bypass port such that when the bypass is capped off the flow through the system increases to 75 SCFM ( $50 \%$ increase).

- After the airflow has stabilized at 50 SCFM, start the data acquisition system to record data every second. Wait ten seconds and then cap off the bypass port. Hait thirty seconds. Remove the 
cap from the bypass port. Wait thirty seconds. Stop the data acquisition system.

- Install the cap on the bypass port and set the nominal airflow through the system at 50 SCFM. Remove the cap and adjust the bypass vaive to adjust the airflow through the system measures 25 SCFM ( $50 \%$ decrease).

- Reinstall the bypass cap and allow the airflow to stabilize at 50 SCFM. Start the data acquisition system to record data every second. Wait ten seconds and then remove the cap from the bypass port. Wait thirty seconds. Reinstall the cap on the bypass port. Wait thirty seconds. Stop the data acquisition system.

- Set the nominal airflow through the system to 120 SCFM. Use the two gate valves near the blower to adjust the airflow through the bypass port such that when the bypass is capped off the flow through the system increases to 180 SCFM ( $50 \%$ increase).

- After the airflow has stabilized at 120 SCFM, start the data acquisition system to record data every second. Wait ten seconds and then cap off the bypass port. Wait thirty seconds. Remove the cap from the bypass port. Wait thirty seconds. Stop the data acquisition system.

- Install the cap on the bypass port and set the nominal airflow through the system at 120 SCFM. Remove the cap and adjust the bypass valve to adjust the airflow through the system measures 60 SCFM (50\% decrease).

- Reinstall the bypass cap and allow the airflow to stabilize at 120 SCFM. Start the data acquisition system to record data every second. Wait ten seconds and then remove the bypass port. Wait thirty seconds. Reinstall the cap on the bypass port. Wait thirty seconds. Stop the data acquisition system.

- Fill out the top of a Flow Meter Stability Test Data Sheet.

- Start the air supply system and set the air flow to $160 \mathrm{ft} / \mathrm{min}$. Allow the airflow to stabilize. Start the data acquisition system to automatically log data for the next 24 hours. Record the airstream temperature, the reference differential pressure, the reference static air pressure, the output of the flow meter being tested, the test flow meter static pressure and the system relative humidity.

- After the 24 hours has elapsed, stop the air supply system, evaluate the test data, and determine if any additional testing is required. If not, proceed with the next flow meter.

\subsubsection{Air Monitor Corporation Flow Meter Testing}

- Install the flow meter where indicated in Figure 1. Drill additional mounting holes as required. 
- Connect power to the flow meter and connect its 4-20 mA output to the data acquisition system.

- Program the flow meter per the manufacturer's instructions to measure flow in the $0-400$ SCFM range.

- Fill out the top of the Flow Meter Test Data Sheets ( $A$ and $B$ ).

- Start the blower and set the air flow as shown in the Nominal Air Flow Column on the Test Data Sheet. Allow the airflow to stabilize. Record the airstream temperature, the reference differential pressure, the reference static air pressure, the output of the flow meter being tested and the test flow meter static pressure. Repeat these steps until the Test Data Sheet is filled out.

- Fill out the top of a Flow Meter Step Response Test Data Sheet.

- Set the nominal airflow through the system to 50 SCFM. Use the two gate valves near the blower to adjust the airflow through the bypass port such that when the bypass is capped off the flow through the system increases to 75 SCFM (50\% increase).

- After the airflow has stabilized at 50 SCFM, start the data acquisition system to record data every second. Wait ten seconds and then cap off the bypass port. Wait thirty seconds. Remove the cap from the bypass port. Wait thirty seconds. Stop the data acquisition system.

- Install the cap on the bypass port and set the nominal airflow through the system at 50 SCFM. Remove the cap and adjust the bypass valve to adjust the airflow through the system measures 25 SCFM (50\% decrease).

- Reinstall the bypass cap and allow the airflow to stabilize at 50 SCFM. Start the data acquisition system to record data every second. Wait ten seconds and then remove the cap from the bypass port. Wait thirty seconds. Reinstall the cap on the bypass port. Wait thirty seconds. Stop the data acquisition system.

- Set the nominal airflow through the system to 120 SCFM. Use the two gate valves near the blower to adjust the airflow through the bypass port such that when the bypass is capped off the flow through the system increases to 180 SCFM ( $50 \%$ increase).

- After the airflow has stabilized at 120 SCFM, start the data acquisition system to record data every second. Wait ten seconds and then cap off the bypass port. Wait thirty seconds. Remove the cap from the bypass port. Wait thirty seconds. Stop the data acquisition system.

- Install the cap on the bypass port and set the nominal airflow through the system at 120 SCFM. Remove the cap and adjust the bypass valve to adjust the airflow through the system measures 60 SCFM ( $50 \%$ decrease). 
- Reinstall the bypass cap and allow the airflow to stabilize at 120 SCFM. Start the data acquisition system to record data every second. Wait ten seconds and then remove the bypass port. Wait thirty seconds. Reinstall the cap on the bypass port. Wait thirty seconds. Stop the data acquisition system.

- Fill out the top of a Flow Meter Stability Test Data Sheet.

- Start the air supply system and set the air flow to $160 \mathrm{ft} / \mathrm{min}$. Allow the airflow to stabilize. Start the data acquisition system to automatically $10 \mathrm{~g}$ data for the next 24 hours. Record the airstream temperature, the reference differential pressure, the reference static air pressure, the output of the flow meter being tested, the test flow meter static pressure and the system relative humidity.

- After the 24 hours has elapsed, stop the air supply system, evaluate the test data, and determine if any additional testing is required. If not, proceed with the next flow meter.

\subsubsection{Panametrics Flow Meter Testing}

- Install the flow meter where indicated in Figure 1. Mount the two saddles horizontally across the duct, centered on the $6^{\prime}-11^{\prime \prime}$ distance. See Figure 3 .

- Connect power to the flow meter and connect its 4-20 mA output to the data acquisition system.

- Program the flow meter per the manufacturer's instructions to measure flow in the $0-400$ SCFM range.

- Fill out the top of the Flow Meter Test Data Sheets (A and B).

- Start the blower and set the air flow as shown in the Nominal Air Flow Column on the Test Data Sheet. Allow the airflow to stabilize. Record the airstream temperature, the reference differential pressure, the reference static air pressure, the output of the flow meter being tested and the test flow meter static pressure. Repeat these steps until the Test Data Sheet is filled out.

- Fill out the top of a Flow Meter Step Response Test Data Sheet.

- Set the nominal airflow through the system to 50 SCFM. Use the two gate valves near the blower to adjust the airflow through the bypass port such that when the bypass is capped off the flow through the system increases to 75 SCFM ( $50 \%$ increase).

- After the airflow has stabilized at 50 SCFM, start the data acquisition system to record data every second. Wait ten seconds and then cap off the bypass port. Wait thirty seconds. Remove the cap from the bypass port. Wait thirty seconds. Stop the data acquisition system. 
- Install the cap on the bypass port and set the nominal airflow through the system at 50 SCFM. Remove the cap and adjust the bypass valve to adjust the airflow through the system measures 25 SCFM (50\% decrease).

- Reinstall the bypass cap and allow the airflow to stabilize at 50 SCFM. Start the data acquisition system to record data every second. Wait ten seconds and then remove the cap from the bypass port. Wait thirty seconds. Reinstall the cap on the bypass port. Wait thirty seconds. Stop the data acquisition system.

- Set the nominal airflow through the system to 120 SCFM. Use the two gate valves near the blower to adjust the airflow through the bypass port such that when the bypass is capped off the flow through the system increases to 180 SCFM (50\% increase).

- After the airflow has stabilized at 120 SCFM, start the data acquisition system to record data every second. Wait ten seconds and then cap off the bypass port. Wait thirty seconds. Remove the cap from the bypass port. Wait thirty seconds. Stop the data acquisition system.

- Install the cap on the bypass port and set the nominal airflow through the system at 120 SCFM. Remove the cap and adjust the bypass valve to adjust the airflow through the system measures 60 SCFM ( $50 \%$ decrease).

- Reinstall the bypass cap and allow the airflow to stabilize at 120 SCFM. Start the data acquisition system to record data every second. Wait ten seconds and then remove the bypass port. Wait thirty seconds. Reinstall the cap on the bypass port. Wait thirty seconds. Stop the data acquisition system.

- Fill out the top of a Flow Meter Stability Test Data Sheet.

- Start the air supply system and set the air flow to $160 \mathrm{ft} / \mathrm{min}$. Allow the airflow to stabilize. Start the data acquisition system to automatically $\log$ data for the next 24 hours. Record the airstream temperature, the reference differential pressure, the reference static air pressure, the output of the flow meter being tested, the test flow meter static pressure and the system relative humidity.

- After the 24 hours has elapsed, stop the air supply system, evaluate the test data, and determine if any additional testing is required. If not, proceed with the high humidity testing.

\subsection{High Humidity Testing}

For this portion of the test the airstream humidity will be maintained at $50-90 \%$ r.h. . 
WHC-SD-WM-TP-441 REV 0

\subsubsection{Sierra Flow Meter Testing}

- Install the flow meter where indicated in Figure 1 using the saddle clamp provided as shown in figure 2.

- Connect power to the flow meter and connect its 4-20 mA output to the data acquisition system.

- Program the flow meter per the manufacturer's instructions to measure flow in the 0-400 SCFM range.

- Fill out the top of a Flow Meter Test Data Sheet.

- Start the air supply system and set the air flow to $160 \mathrm{ft} / \mathrm{min}$. Allow the airflow to stabilize. Start the humidification system and allow the system to reach 50 to $90 \%$ r.h.. Start the data acquisition system to automatically log data for the next 48 hours. Record the airstream temperature, the reference differential pressure, the reference static air pressure, the output of the flow meter being tested, the test flow meter static pressure and the system relative humidity.

\subsubsection{Intek Flow Meter Testing}

- Install the flow meter where indicated in Figure 1 using the saddle clamp provided as shown in Figure 2.

- Connect power to the flow meter and connect its 4-20 mA output to the data acquisition system.

- Program the flow meter per the manufacturer's instructions to measure flow in the $0-400$ SCFM range.

- Fill out the top of a Flow Meter Test Data Sheet.

- Start the air supply system and set the air flow to $160 \mathrm{ft} / \mathrm{min}$. Allow the airflow to stabilize. Start the humidification system and allow the system to reach 50 to $90 \%$ r.h.. Start the data acquisition system to automatically $1 \mathrm{og}$ data for the next 48 hours. Record the airstream temperature, the reference differential pressure, the reference static air pressure, the output of the flow meter being tested, the test flow meter static pressure and the system relative humidity.

\subsubsection{Air Monitor Corporation Flow Meter Testing}

- Install the flow meter where indicated in Figure 1. Drill additional mounting holes as required.

- Connect power to the flow meter and connect its 4-20 mA output to the data acquisition system. 
- Program the flow meter per the manufacturer's instructions to measure flow in the $0-400$ SCFM range.

- Fill out the top of a Flow Meter Test Data Sheet.

- Start the air supply system and set the air flow to $160 \mathrm{ft} / \mathrm{min}$. Allow the airflow to stabilize. Start the humidification system and allow the system to reach 50 to $90 \%$ r.h.. Start the data acquisition system to automatically log data for the next 48 hours. Record the airstream temperature, the reference differential pressure, the reference static air pressure, the output of the flow - meter being tested, the test flow meter static pressure and the system relative humidity.

\subsubsection{Panametrics Flow Meter Testing}

- Install the flow meter where indicated in Figure 1. Mount the two saddles horizontally across the duct, centered on the $6^{\prime}-11^{\prime \prime}$ distance. See Figure 3.

- Connect power to the flow meter and connect its 4-20 mA output to the data acquisition system.

- Program the flow meter per the manufacturer's instructions to measure flow in the 0-400 SCFM range.

- Fill out the top of a Flow Meter Test Data Sheet.

- Start the air supply system and set the air flow to $160 \mathrm{ft} / \mathrm{min}$.

Allow the airflow to stabilize. Start the humidification system and allow the system to reach 50 to $90 \%$ r.h.. Start the data acquisition system to automatically $l 0 g$ data for the next 48 hours. Record the airstream temperature, the reference differential pressure, the reference static air pressure, the output of the flow meter being tested, the test flow meter static pressure and the system relative humidity.

\subsection{SAFETY}

No unique or unusual industrial, radiological, chemical, fire, release of energy, or criticality safety hazards are involved with performing or supporting these tests. Only the test director, cognizant test engineers and/or their approved personnel shall operate the test equipment. A Hanford Job Hazard Analysis, a 306E Specific Job Hazard Analysis and an Environmental Compliance Screening Checklist for the $306 \mathrm{E}$ Complex will be prepared prior to the start of testing. A prejob safety briefing will be conducted with all test personnel as documented on the Job Hazard Analysis Signoff Sheet.

The air blower has a sound pressure level of 85-95 $\mathrm{dB}(\mathrm{A})$ at three feet. The intake and bypass ports will be diverted downward to reduce the noise level but hearing protection may still be required around the test mockup. Industrial Hygiene will make a final determination after the system is operable. 


\section{WHC-SD-WM-TP-44I REV O}

Compressed air ( 30 psi) and pressurized water ( 20 psi) will be used during the humidity portion of this test. Normal industrial safety precautions should be used with the air and water.

The $306 \mathrm{E}$ Facility Manager or his designee must be notified prior to commencement of testing.

\subsection{QUALITY ASSURANCE}

A Quality Assurance representative shall review this document as well as the test report when it is prepared.

No witnesses or hoid points are required during testing but interested observers will be allowed.

\subsection{ORGANIZATION AND FUNCTION RESPONSIBILITIES}

\subsection{Characterization Equipment Development (75240)}

A Characterization Equipment Development engineer shall review this document as well as the test report when it is prepared.

\subsection{Equipment Development (8A200)}

Equipment Development will provide a Test Director for this test. The director will have overall responsibility for the performance of this test. Equipment Development will also provide personnel for test preparation, test maintenance, equipment disassembly and general assistance during testing.

\subsection{Analytical Services (5A620)}

Analytical Services will prepare this test plan and the test report for this testing. Analytical Services will also provide the Test Performer for this test.

\subsection{SCHEDULE:}

Testing will start as soon as this Test $P$ lan is approved and released by Document Control. Testing will last for approximately five weeks, after which the test data will be evaluated and the test report prepared.

\subsection{REPORTS}

The test data and a recommendation for a flow meter to be installed in the field wi]l be presented in WHC-SD-WM-TRP-254, Test Report of Evaluation of Primary Exhaust Ventilation Flow Meters for Double Shell Hydrogen Watch List Tanks, following the completion of the testing. 


\subsection{REFERENCES}

12.1 Westinghouse Hanford Company, WHC-SD-WM-[RR-003, Rev. 0, Design Requirements Document - Primary Ventilation Flow Monitoring for DSTs on the Hydrogen Watch List, 10/9/95, Richland, Washington.

12.2 Westinghouse Hanford Company, WHC-SD-WM-ETP-156, Rev. 0, Task Plan for Design and Installation of Primary Exhaust Ventilation Flow Monitoring in Double Shell Hydrogen Watch List Tanks, 9/7/95, Richland, Washington.

12.3 Westinghouse Hanford Company, WHC-SD-WM-CDR-026, Rev. 0, Engineering Study and Conceptual Design Report for Primary Ventilation Duct Flow Monitoring, 10/31/95, Richland, Washington.

12.4 Westinghouse Hanford Company, WHC-SD-WM-ETP-178, Rev. 0, Task Plan for the Selection and Evaluation of Flow Monitoring Instrumentation to be Used on the Primary Exhaust Ventilation in Double Shell Hydrogen Watch List Tanks, 12/4/95, Richland, Washingtor. 


\section{FIGURE 2 - INSERTION-TYPE FLOW METER MOUNTING}

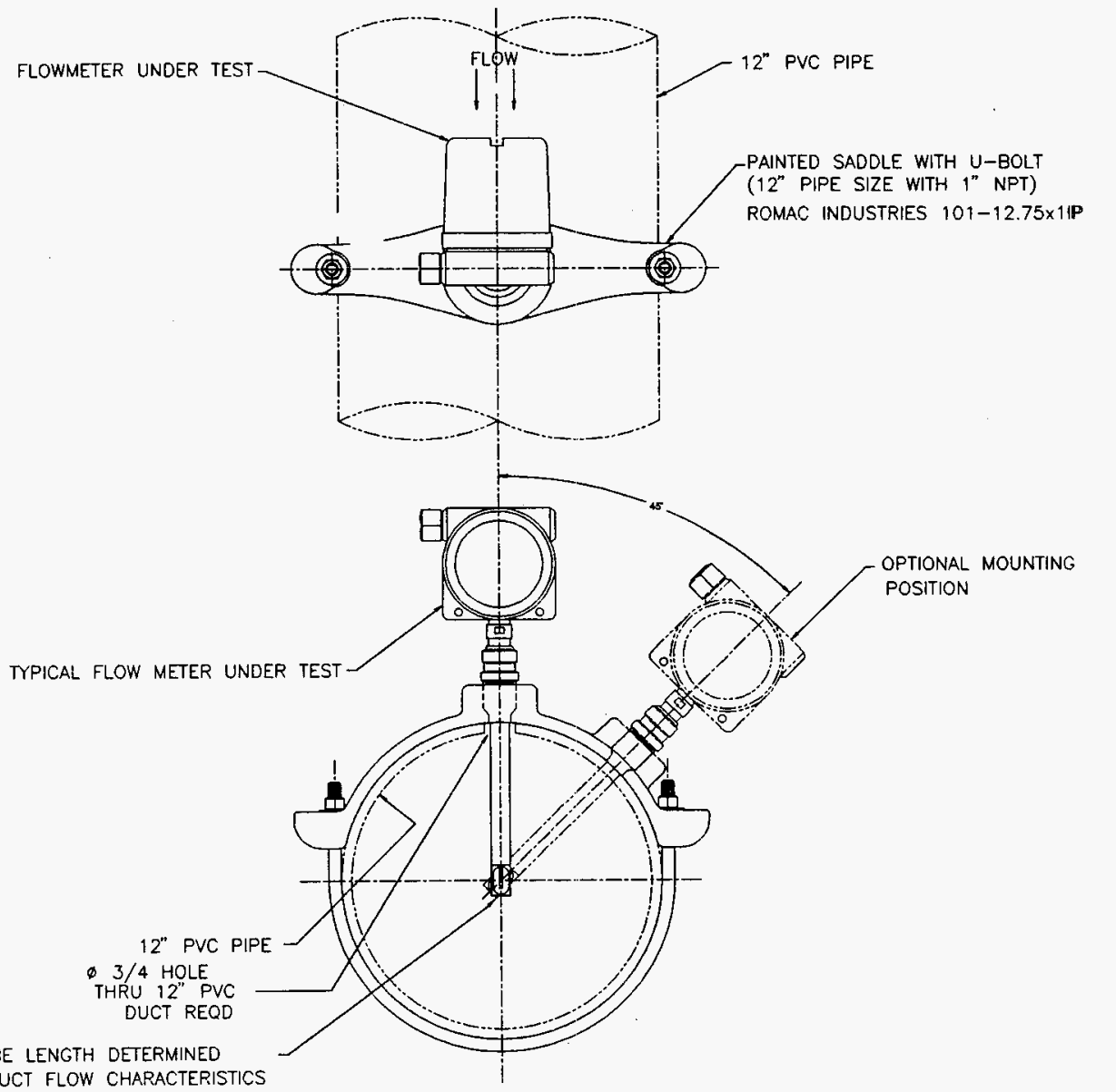

BY DUCT FLOW CHARACTERISTICS

(PROBE SHALL BE PLACED AT

AVERAGE FLOW) 
WHC-SO-WM-TP-441, REV. 0

FIGURE 3 - ULTRASONIC FLOW METER MOUNTING

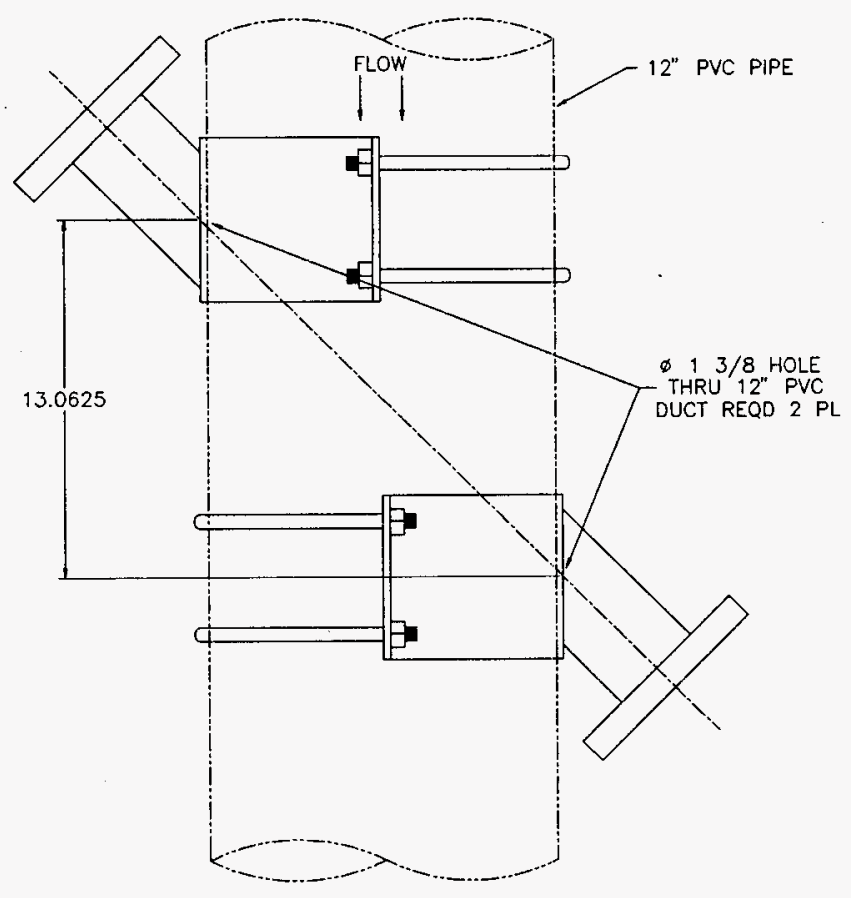

INSTALLATION DETAIL FOR PANAMETRICS ULTRASONIC FLOW METER TRANSDUCERS 


\section{TEST EQUIPMENT DATA SHEET}

- Laminar Flow Element, Meriam Instrument Model 50MC2-4, nominal $400 \mathrm{scfm}$ air flow at 8 " WC and 70 degrees $F$ and $29.92 " \mathrm{Hg}$ abs.

Serial Number

Factory Calibration:

- Ashcroft ATE-100 Handheld Pressure Calibrator, Port 1: 0-25 in. $\mathrm{H}_{2} \mathrm{O}$ input range, Port 2: 0-30 psia input range.

Serial Number

Calibration:

- Absolute Pressure Transmitter, Rosemount Model 3051C, 0-30 psia input range, 4-20 mA output.

Serial Number

Calibration:

- Humidity Probe

Model Number

Serial Number.

Calibration:

- RTD, Platinum, 100 Ohm, Gordon Model RFHLOTK100CA200

- Temperature Indicator/Transmitter, Newport Electronics Mode 1 INFU-0010-DCI

Serial Number

Calibration:

- Computer, IBM PC/XT/AT, Model Number

Serial Number Property Number

- Data acquisition software

Model Number Version

Serial Number

- Power Supply, $120 \mathrm{~V} \mathrm{AC}$ input, $24 \mathrm{~V} \mathrm{DC}$ output.

Model Number Serial Number

Test Performer Date

Test Director Date 


\section{FLOW METER TEST DATA SHEET - AMBIENT, PAGE A}

Flow Meter Manufacturer

Model Number

Serial Number

Ambient Temperature

Ambient Humidity

Flow Meter mounting location, orientation

Butterfly Valve Position

Probe insertion depth

Data File Name

\begin{tabular}{|c|c|c|c|c|c|c|c|}
\hline $\begin{array}{c}\text { Nominal } \\
\text { Air } \\
\text { Flow } \\
\text { (SCFM) } \\
\pm 5 \\
\end{array}$ & $\begin{array}{l}\text { Reference } \\
\text { Air flow } \\
\text { (SCFM) }\end{array}$ & $\begin{array}{l}\text { Airstrean } \\
\text { Temp. } \\
\left({ }^{\circ} \mathrm{F}\right)\end{array}$ & $\begin{array}{l}\text { Reference } \\
\text { Diff. } \\
\text { Pressure } \\
\text { (in. } \mathrm{H}_{2} \text { D) }\end{array}$ & $\begin{array}{l}\text { Reference } \\
\text { Static } \\
\text { Pressure } \\
\text { (psia) }\end{array}$ & $\begin{array}{l}\text { Flow Meter } \\
\text { Static } \\
\text { Pressure } \\
\text { (psia) }\end{array}$ & $\begin{array}{l}\text { Flow Meter } \\
\text { Output } \\
\end{array}$ & $\begin{array}{l}\text { Calculated } \\
\text { flow Meter } \\
\text { Air Flow } \\
\text { (SCFM) }\end{array}$ \\
\hline \multicolumn{8}{|l|}{10} \\
\hline \multicolumn{8}{|l|}{20} \\
\hline \multicolumn{8}{|l|}{30} \\
\hline \multicolumn{8}{|l|}{40} \\
\hline \multicolumn{8}{|l|}{50} \\
\hline \multicolumn{8}{|l|}{60} \\
\hline \multicolumn{8}{|l|}{70} \\
\hline \multicolumn{8}{|l|}{80} \\
\hline \multicolumn{8}{|l|}{120} \\
\hline \multicolumn{8}{|l|}{160} \\
\hline \multicolumn{8}{|l|}{200} \\
\hline \multicolumn{8}{|l|}{240} \\
\hline \multicolumn{8}{|l|}{280} \\
\hline \multicolumn{8}{|l|}{320} \\
\hline \multicolumn{8}{|l|}{340} \\
\hline \multicolumn{8}{|l|}{320} \\
\hline 280 & & & & & & & \\
\hline
\end{tabular}

Test Performer

Date

Test Director Date 
WHC-SD-WM-TP-441 REV 0

\section{FLOW METER test DATA SHEET - AMBIENT, PAGE B}

Flow Meter Manufacturer

Model Number

Serial Number

Ambient Temperature

Ambient Humidity

Flow Meter mounting location, orientation

Butterfly Valve Position

Probe insertion depth

Data File Name

\begin{tabular}{|c|c|c|c|c|c|c|c|}
\hline $\begin{array}{c}\text { Nominat } \\
\text { Air } \\
F \text { l ow } \\
\text { (SCFM) } \\
\pm 5\end{array}$ & $\begin{array}{l}\text { Reference } \\
\text { Air Flow } \\
\text { (SCFM) }\end{array}$ & $\begin{array}{l}\text { Airstream } \\
\text { Temp. } \\
\left.6^{\circ} \mathrm{F}\right)\end{array}$ & $\begin{array}{l}\text { Reference } \\
\text { Diff. } \\
\text { Pressure } \\
\text { (in. } \mathrm{H}_{2} \mathrm{O} \text { ) }\end{array}$ & $\begin{array}{l}\text { Reference } \\
\text { Static } \\
\text { Pressure } \\
\text { (psia) }\end{array}$ & $\begin{array}{l}\text { Flow Meter } \\
\text { static } \\
\text { Pressure } \\
\text { (psia) }\end{array}$ & $\begin{array}{l}\text { Flow Meter } \\
\text { Output } \\
(\end{array}$ & $\begin{array}{l}\text { Calculated } \\
\text { Flow Meter } \\
\text { Air Flow } \\
\text { (SCFM) }\end{array}$ \\
\hline 240 & & & & & & & \\
\hline 200 & & & & & & & \\
\hline 160 & & & & & & & \\
\hline 120 & & & & & & & \\
\hline 80 & & & & & & & \\
\hline 70 & & & & & & & \\
\hline 60 & & & & & & & \\
\hline 50 & & & & & & & \\
\hline 40 & & & & & & & \\
\hline 30 & & & & & & & \\
\hline 20 & & & & & & & \\
\hline 10 & & & & & & & ' \\
\hline
\end{tabular}

COMMENTS:

Test Performer

Date

Test Director

Date 


\section{FLOW METER TEST DATA SHEET - HIGH HUMIDITY}

Flow Meter Manufacturer

Model Number

Serial Number

Ambient Temperature

Ambient Humidity

Flow Meter mounting location, orientation

Butterfly Valve Position

Probe insertion depth

Data File Name

\begin{tabular}{|c|c|c|c|c|c|c|c|}
\hline & $\begin{array}{l}\text { Reference } \\
\text { Air Flow } \\
\text { (SCFM) }\end{array}$ & $\begin{array}{l}\text { Airstream } \\
\text { Temp. } \\
\left({ }^{\circ} \text { F) }\right.\end{array}$ & $\begin{array}{l}\text { Reference } \\
\text { Diff. } \\
\text { Pressure } \\
\left(\text { in. } \mathrm{H}_{2} \mathrm{O}\right)\end{array}$ & $\begin{array}{l}\text { Reference } \\
\text { Static } \\
\text { Pressure } \\
\text { (psia) }\end{array}$ & $\begin{array}{l}\text { Flan Meter } \\
\text { Static } \\
\text { Pressure } \\
\text { (psia) } \\
\end{array}$ & $\begin{array}{l}\text { Flow Meter } \\
\text { Output }\end{array}$ & $\begin{array}{l}\text { Calculated } \\
\text { Flow Meter } \\
\text { Air Flow } \\
\text { (SCFM) }\end{array}$ \\
\hline START & & & & & & & \\
\hline $24 \mathrm{hrs}$ & & & & & & & \\
\hline END & & & & & & & \\
\hline & & & & & & & \\
\hline & & & & & & & \\
\hline
\end{tabular}

Comments:

Test Performer

Date

Test Director

Date 
WHC-SD-WM-TP-441 REV 0

\section{FLOW METER STABILITY TEST DATA SHEET}

Flow Meter Manufacturer

Model Number

Serial Number

Ambient Temperature

Ambient Humidity

Flow Meter mounting location, orientation

Butterfly Valve Position

Probe insertion depth

Data File Name

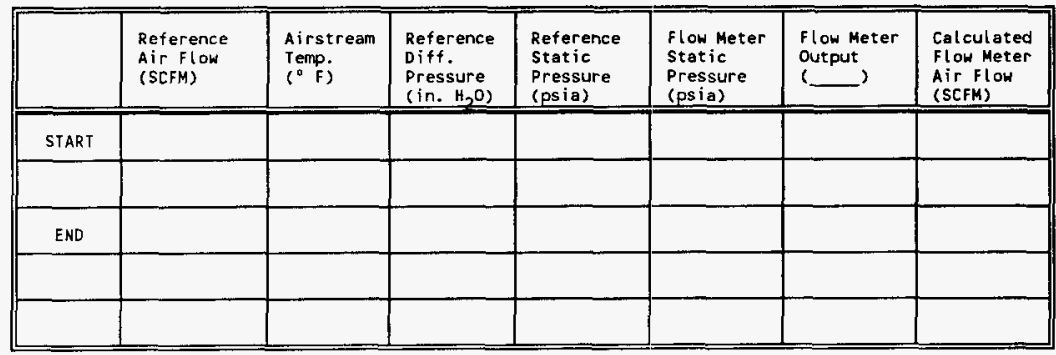

Comments:

Test Performer

Date

Test Director

Date 
WHC-SD-WM-TP-441 REV 0

\section{STEP RESPONSE TEST DATA SHEET}

Flow Meter Manufacturer

Model Number

Serial Number

Ambient Temperature

Ambient Humidity

Flow Meter mounting location, orientation

Butterfly Valve Position

Probe insertion depth

Data File Name

\begin{tabular}{|c|c|c|c|c|c|c|c|}
\hline $\begin{array}{c}\text { Nominal } \\
\text { Air } \\
\text { Flow } \\
\text { (SCFM) } \\
\pm 5 \\
\end{array}$ & $\begin{array}{l}\text { Reference } \\
\text { Air Flow } \\
\text { (SCFM) }\end{array}$ & $\begin{array}{l}\text { Airstream } \\
\text { Temp. } \\
\left({ }^{\circ} \mathrm{F}\right)\end{array}$ & $\begin{array}{l}\text { Reference } \\
\text { Diff. } \\
\text { Pressure } \\
\left(\text { in. } \mathrm{H}_{2} \mathrm{O}\right)\end{array}$ & $\begin{array}{l}\text { Reference } \\
\text { Static } \\
\text { Pressure } \\
\text { (psia) }\end{array}$ & $\begin{array}{l}\text { Flow Meter } \\
\text { Static } \\
\text { Pressure } \\
\text { (psia) }\end{array}$ & $\begin{array}{l}\text { Flow Meter } \\
\text { Output } \\
\text { (_ }\end{array}$ & $\begin{array}{l}\text { Calculated } \\
\text { Flow Meter } \\
\text { Air Flow } \\
\text { (SCFM) }\end{array}$ \\
\hline \multicolumn{8}{|l|}{50} \\
\hline 75 & & & & & & & \\
\hline \multicolumn{8}{|c|}{ RESPONSE TIME: } \\
\hline \multicolumn{8}{|l|}{50} \\
\hline 25 & & & & & & & \\
\hline \multicolumn{8}{|c|}{ RESPONSE TIME: } \\
\hline \multicolumn{8}{|l|}{120} \\
\hline \multicolumn{8}{|l|}{180} \\
\hline \multicolumn{8}{|c|}{ RESPONSE TIME: } \\
\hline \multicolumn{8}{|l|}{120} \\
\hline 60 & & & & & & & \\
\hline
\end{tabular}

Test Performer

Date

Test Director

Date 
WHC-SD-WM-TP-441 REV 0

Flow and Velocity Reference Table

(for 12-5/8" diameter duct)

\begin{tabular}{|l|l|l|l|}
\hline CFM & $\mathrm{m}^{3} / \mathrm{s}$ & $\mathrm{m} / \mathrm{s}$ & $\mathrm{ft} / \mathrm{min}$ \\
\hline 10 & $4.72 \mathrm{E}-3$ & 0.066 & 13.0 \\
\hline 20 & $9.44 \mathrm{E}-3$ & 0.132 & 26.0 \\
\hline 30 & 0.014 & 0.196 & 39.0 \\
\hline 40 & 0.019 & 0.266 & 52.0 \\
\hline 50 & 0.024 & 0.336 & 65.0 \\
\hline 60 & 0.028 & 0.392 & 78.0 \\
\hline 70 & 0.033 & 0.462 & 91.0 \\
\hline 80 & 0.038 & 0.532 & 104.0 \\
\hline 120 & 0.057 & 0.798 & 156.0 \\
\hline 160 & 0.076 & 1.064 & 208.0 \\
\hline 200 & 0.094 & 1.315 & 260.0 \\
\hline 240 & 0.113 & 1.582 & 312.0 \\
\hline 280 & 0.132 & 1.847 & 364.0 \\
\hline 320 & 0.151 & 2.113 & 416.0 \\
\hline 340 & 0.161 & 2.247 & 442.0 \\
\hline & & & \\
\hline & & & \\
\hline
\end{tabular}




\begin{tabular}{|c|c|c|c|c|c|}
\hline \multicolumn{6}{|c|}{ DISTRIBUTION SHEET } \\
\hline To & \multirow{2}{*}{\multicolumn{3}{|c|}{$\begin{array}{l}\text { From } \\
\text { W. E. Willingham Jr. }\end{array}$}} & \multicolumn{2}{|l|}{ Page 1 of 1} \\
\hline Distribution & & & & \multicolumn{2}{|l|}{ Date $5 / 1 / 96$} \\
\hline \multirow{2}{*}{\multicolumn{4}{|c|}{$\begin{array}{l}\text { Project Title/Work Order } \\
\text { Characterization }\end{array}$}} & \multicolumn{2}{|c|}{ EDT No. 615719} \\
\hline & & & & \multicolumn{2}{|l|}{ ECN No. } \\
\hline Name & MSIN & $\begin{array}{l}\text { Tiext } \\
\text { With All } \\
\text { Attach. }\end{array}$ & Text Only & $\begin{array}{l}\text { Attach./ } \\
\text { Appendix } \\
\text { Only }\end{array}$ & $\begin{array}{c}\text { EDT/ECN } \\
\text { Only }\end{array}$ \\
\hline $\begin{array}{l}\text { W. E. Willingham Jr. } \\
\text { S. K. Farnworth } \\
\text { T. C. Schneider } \\
\text { D. D. Tate } \\
\text { E. A. Smith } \\
\text { D. B. Engelman } \\
\text { J. W. Lentsch } \\
\text { B. J. Hug } \\
\text { J. R. Thielges } \\
\text { D. G. Panther } \\
\text { Central Files }\end{array}$ & $\begin{array}{l}\text { H6- } 11 \\
\text { H5-56 } \\
\text { L6-37 } \\
\text { L6-37. } \\
\text { B } 4-40 \\
\text { L6-37 } \\
\text { S7- } 12 \\
\text { L6-35 } \\
\text { L6-38 } \\
\text { L6-39 } \\
\text { A3 }-88\end{array}$ & $\begin{array}{l}x \\
x \\
x \\
x \\
x \\
x \\
x \\
x \\
x \\
x \\
x\end{array}$ & . & & \\
\hline
\end{tabular}

